\title{
Ikasle autoktonoak eta ikasle etorkinak Bilboko eskoletan: eskola mota eta praktika linguistikoak
}

\author{
Naiara Berasategi Sancho \\ Didaktika eta Eskola Antolakuntza Saila \\ Bilboko Irakasleen Unibertsitate Eskola \\ Euskal Herriko Unibertsitatea (UPV/EHU)
}

DOI: $10.1387 / \operatorname{tantak.16336}$

GAKO-HITZAK: bigarren hezkuntza, hizkuntza-ereduak, ikasle etorkinak, hizkuntza-praktikak

\section{SARRERA}

Ikasle autoktonoek eta ikasle etorkinek aukeratzen duten eskola eta erabiltzen duten edo dituzten hizkuntzak zeintzuk diren aztertzea du helburu lan honek. Zehazki, Bilbon Derrigorrezko Bigarren Hezkuntzako 2. eta 4. mailan eskolatuta dauden ikasleak aztertuko dira. Horretarako, inkesta batez baliatuko gara.

Etorkinen etorrerak eskolaren eremuan orain arte ezezagunak edo landugabeak ziren hainbat auzi sortu du. Horien artean, hizkuntza edo kultur kudeaketaren auzia da jomugetako bat. Gure ikerketan parte hartu duten ikasleek Bilbon ikasten dute, testuinguru ez oso euskaldun batean, eta etorkin kopuru esanguratsua dagoen gunean kokatzen dira. Interesgarria gerta liteke, halako baldintzetan, ikasle horiek zer eskola aukeratzen duten eta zer hizkuntza praktikatzen duten jakitea; eta jatorriaren arabera desberdintasunik ote dagoen ikustea. Halaber, ikasle horiek aukeratzen duten eskola mota nolakoa den jakitea garrantzitsua izango da, horrek ere baldintzatuko baitu euren hizkuntza-praktika.

Sarrera honen ondotik, populazioaren bilakaeraz, oro har, eta ikasle etorkinen eskolatzeaz jardungo dugu, gure ikerketa imigrazioaren fenomeno berri horretan kokatze aldera. Bigarren atalean, hizkuntzaren eta kulturaren kudeaketaren inguruko hainbat zertzelada emango ditugu. Hirugarren atalean, ikerketaren helburuak aurkeztuko ditugu eta, ondorengo atalean, ikerketa aurrera eramateko erabili dugun metodologia azalduko 
dugu. Bosgarren atalean, ikerketaren emaitzak aurkeztuko ditugu. Bukatzeko, ikasleen azterketatik ateratako emaitzak eztabaidatuko ditugu.

\section{POPULAZIOAREN BILAKAERA ETA IKASLE ETORKINAK EAE-KO ESKOLETAN}

Migrazioa ez da kontu berria, asko izan dira Euskal Herritik kanpora emigratu dutenak eta, aldi berean, asko izan dira hona etorri direnak. Mundu mailan nabaria da lurralde batetik besterako jendartearen mugimendua. Zaila da zehazki esatea zenbat nazioarteko migrazio dagoen munduan, horietako asko egoera «irregularrean» edo «ilegalean» bizi baitira. Migrazioetarako Nazioarteko Erakundeak (MNE, 2011) emandako datuen arabera, 214 milioi dira nazioarteko migrazioak mundu mailan, populazio osoaren \% 3,3. Migrazioa asko hazi da azken urteetan eta 150 milioi izatetik 214 milioi izatera pasatu da. Alabaina, etorkinen kopurua asko aldatzen da lurralde batzuetatik bestera. Etorkin kopurua altua duten lurraldeen artean, aipatu beharko lirateke Qatar (\% 87), Arabiar Emirerri Batuak (\% 70), Jordania (\% 46), Singapur (\% 41) eta Saudi Arabia (\% 28). Etorkin kopuru baxua duten lurraldeak, aldiz, honako hauek dira: Hegoafrika (\% 3,7), Eslovakia (\% 2,4), Turkia (\% 1,9), Japonia (\% 1,7), Nigeria $(\% 0,7)$, Errumania $(\% 0,6)$, India $(\% 0,4)$ eta Indonesia $(\% 0,1)$.

Castels eta Millerek (2003) diotenaren arabera, mugimendu hori ez da, nolabait esateko, zoriz edo kasualitatez gertatzen den zerbait; emigratzera behartzen duten arrazoiak oso konplexuak dira eta elkarrekin lotuta daude. Besteak beste, norbanakoen erabakiekin, prozesu familiar eta sozialekin, eta testuinguru sozioekonomikoekin edo politikoekin izan ohi dute zerikusia.

Euskal Herrian ere migrazioaren fenomenoak izugarrizko garrantzia izan du historiaren joanean, bai euskal emigranteak askotan joan direlako beste latitude batzuetara, baita Espainiako eta Frantziako estatuetatik immigranteak etorri direlako ere gurera (Albite, 2008). Alabaina, azpimarratu beharra dago migrazio-prozesuak gurean nolabaiteko bizkortzea izan badu ere - egun \% 6,3 da etorkin kopurua EAEn (Eustat, 2015) -, oraindik datu kuantitatiboei dagokienez oso kopuru txikien aurrean gaudela. Hala ere, kualitatiboki EAE oso egoera anitzean dagoela esan behar da; Urangak eta beste egile batzuek (2008) egindako ikerketa batean aditzera ematen da euskaraz eta espainieraz gain 100 hizkuntza detektatu direla EAEn eta Nafarroan.

Etorkinen etorrerak eskolan ere izan du bere isla. Azken urteetan ikasle etorri berrien bilakaera nabaria izan da. Egun, ikasle horien kopurua derrigorrezko hezkuntzan \% 7,3 da (Euskadiko Eskola Kontseilua, 2013). Jatorriari dagokionez, latinoamerikar populazioa nagusitzen da, atzerritar populazioaren ia erdia osatzen baitu $(\%, 40,9)$. Nabarmenak dira ere europarren kopurua $(\% 16,9)$ eta afrikarren kopurua (\% 29). Ikasle horiek, euskaraz eta espainieraz gain, bestelako hizkuntzak dakizkite. Beste hizkuntza ho- 
rietatik nagusia espainiera da. Ondoren, $\% 10$ gainditzen duten hizkuntzak honako hauek dira: portugesa (komunitate lusofonoa edo portuges-hiztuna: Portugal, Brasil, Mozambike, Angola eta Cabo Verde), arabiera eta tamazighta. Txinera eta errumaniera \% 10en azpitik kokatzen dira. Argi dago, beraz, ikas zentroetan beste hizkuntza batzuk dakizkiten ikasleen presentzia gero eta nabariagoa dela (Etxeberria, 2006) (1. grafikoa).

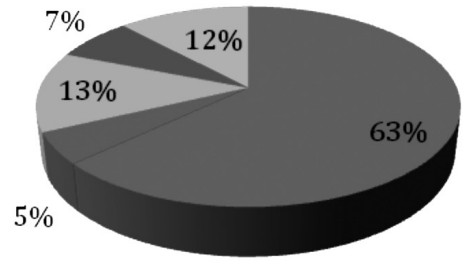

$$
\begin{aligned}
& \text { - Latinoamerika } \\
& \text { - Txina } \\
& \text { - Port-Bras } \\
& \text { - Errumania } \\
& \text { — Maroko }
\end{aligned}
$$

Iturria: Etxeberria, 2006.

$$
\text { 1. grafikoa }
$$

Etorkin ikasleen artean, gehien hitz egiten diren hizkuntzak, 2006 (\%)

Ikasleek, oro har, hautatzen duten sareari dagokionez, bi eredu bereiz daitezkeela dirudi: bata Gipuzkoan eta Bizkaian, eta bestea Araban. Horrela, Araban, etorkinei dagokienez, eskola publikoan \% 82,2 dago matrikulatuta, eta itunpekoan \% 17,8. Bizkaian eta Gipuzkoan, ordea, gehiago dira itunpeko ikastetxeetan matrikulatzen direnak Arabakoekin alderatuz, baina kasu honetan ere publikoetan matrikulatzen da ikasleriaren gehiengoa (Aierdi eta Moreno, 2011) (2. grafikoa). Septien-ek (2006) aipatzen duenez, populazio etorkinak zentro publikoetara jotzeko joera du, baina beste erkidego batzuetan baino kontzentrazio-efektu nabarmenagoekin. Nolanahi ere, eskola-barrutien artean desberdintasunak antzematen direla aipatzen du egileak, itunpeko zentro gehienak Bilbon eta Donostian kokatuta baitaude.

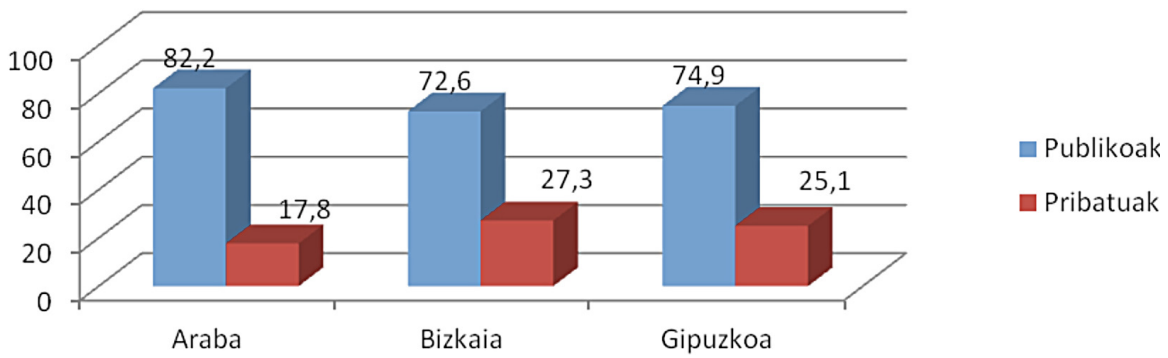

Iturria: Aierdi eta Moreno, 2011 (Guk egindakoa).

2. grafikoa

Ikasle etorkinen banaketa, probintzia eta hezkuntza-sareen arabera, 2010-2011 (\%) 
Hizkuntza-ereduaren arloan, ikasleria osoaren datuei dagokienez, $\%$ 18,78 A ereduan kokatzen da, \% 23,27 B ereduan eta, azkenik, \% 57,55 D ereduan (Eusko Jaurlaritza, 2009). Etorkinen seme-alaben datuei dagokienez, A ereduak biltzen du etorkinen seme-alaben \% 37,57; B ereduak $\%$ 30,34 eta D ereduak, berriz, \% 12,09 (3. grafikoa). Datuek agerian uzten dute, beraz, etorkinen seme-alaben hautuak ez direla ikasleria osoaren parekoak (Eusko Jaurlaritza, 2009). Horiek horrela, hizkuntza-ereduen aukeraketa horrek seme-alaben integrazioan izan ditzakeen inplikazioek kezkatu dituzte azken urteetan zenbait aditu (Barquín, 2007; Euskararen Kontseilua, 2006; Septién, 2006; Zapata, 2006).

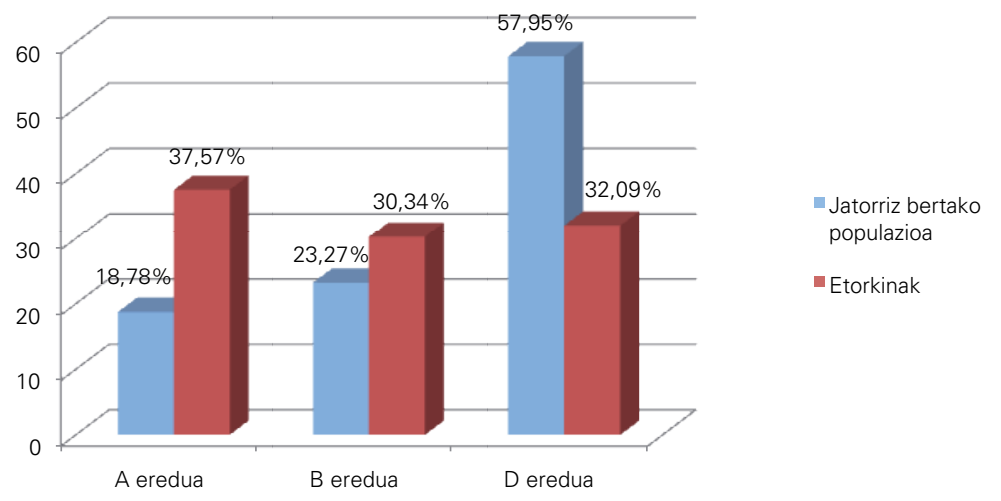

Iturria: Eusko Jaurlaritzako Hezkuntza, Unibertsitate eta Ikerketa saila, 2012 (Guk egindakoa).

3. grafikoa

\section{EAEn, jatorriz bertakoak diren ikasleen eta (ikasle) etorkinen arteko konparaketa, ereduen arabera, 2008-2009 ikasturtea (\%)}

\section{EAEko lege esparrua eskolan, kultura arteko hezkuntza eta hizkuntza aniztasunari dagokienez}

Azken urteetan EAEk bizi duen aniztasun egoera hau kudeatzeko Eusko Jaurlaritzako Hezkuntza Sailetik zenbait neurri hartu dira, ikasle etorri berrien eskolatzea kudeatzeko.

1998. urteko aginduan lehen aldiz arautu ziren ekintza eta neurriak gizarte edo kulturaren ikuspegitik besteak baino egoera txarragoan diren ikasleentzat eta eskolara egokitzeko zailtasun handiak dauzkaten ikasleentzat (Agindua, 164, 1998-08-21). Urte berean Hezkuntza Sailak argitara eman zuen «Eskolan aniztasun etniko eta kulturalari hezkuntza erantzuna emateko orientabideak» liburua (Jaussi Nieva eta Rubio, 1998). Era berean, Euskal Gobernuak 2003. urtean «EAEko ikasle etorkinak epez kanpo eskolatzea arautzeko instrukzioak» deituriko zirkularra onartu zuen esko- 
letan (Eusko Jaurlaritza, 2003). Zirkularraren puntu azpimarragarriak hiru dira: fondo publikoekin mantentzen diren eskoletan etorkin kopuru orekatua lortzea, ikasleak B eta D ereduen bitartez hizkuntza normalizazio prozesuan integratzea eta diagnostiko bat nahiz estrategia bat zehaztea.

Urtebete geroago, «Etorkinak artatzeko programa» sortu zen (Eusko Jaurlaritza, 2004) berariazko hiru helbururi erantzuteko: ikasleek bi hizkuntza ofizialak ahoz eta idatziz menderatzea, gainerako ikasleen curriculum bera izatea eta autonomia garatzea. Horretarako, Gobernuak eskolei eskaini zien Hizkuntza Indartzeko Proiektuak aurkezteko aukera. Proiektu hauen bidez baliabideak eskaini nahi zitzaizkien, Euskal Hezkuntza Sisteman lehen aldiz eskolatzen ziren ikasleen beharrak artatzeko, baldin eta komunikatzeko gabezia handiak bazituzten, eta hizkuntza errefortzua behar bazuten. Zenbait ikerketak adierazi dute (Basurko, Galarreta, Lukas eta Pikabea, 2006; Septien, 2006) giza baliabideen premia ikasleek trataera egoki bat eskura dezaten.

Ondoren, 2007-2010 urte bitarteko programa eskaini zuen: «Kulturartekotasuna eta Ikasle Berrien Inklusiorako Programa 2007-2010». Plana aurreko ebaluazioaren ondoren sortu zen, Immigrazioari buruzko II. Euskal Planaren barnean. Programa hori hiru helburutan egituratzen zen, bakoitza jarduera jakin batzuei lotuta: 1) Kulturarteko hezkuntza bultzatzea, berdintasunean, elkartasunean eta kultura aniztasunarekiko begirunean oinarrituta, 2) Eskolan eta gizartean ikasle iritsi berriekin inklusioa bultzatzea, harrera zein integrazio egokiak bermatuz eta edozein motatako bazterketak saihestuz, 3) Ikasle iritsi berriei eskola-arrakasta lortzen laguntzea, saiatuz gure Autonomia Erkidegoko bi hizkuntza ofizialak ikas ditzaten, batez ere euskarazko ikaskuntza sendotu dezaten, eta familiek euskararekiko jarrera positiboak izan ditzaten.

Gaur egun, indarrean dagoen programa da ikasle etorkinentzako hezkuntza-arretarako programa, eskola-eredu inklusibo eta kulturartekoaren barruan (2012-2015). Plan honen helburu orokorra da hezkuntza-kultura, politika eta jardueretan kulturarteko ikuspegia txertatzea. Horrek lagunduko du, beste ekintza batzuekin batera, berdintasunaren eta guztien eskola-arrakastaren alde apustu egingo duen hezkuntza-sistema bat sendotzen, arrazakeria edota bazterkeria-adierazpen orori aurre egin diezaion.

\section{HIZKUNTZEN ETA KULTUREN KUDEAKETA ESKOLA TESTUINGURUAN}

Etorri berriek, harrera-herrialdera iristean, hainbat zailtasun eta erronkari aurre egin behar diete, eta horien artean bertako hizkuntza edo hizkuntzak ikastea izaten da erronka nagusietakoa. Kasu askotan, etorri berrientzat harrera-lurraldeko hizkuntza edo hizkuntzak erabat arrotzak izaten dira. Baina beste batzuetan ez; izan ere, etorkinen jatorrizko herrialdeko 
hizkuntza eta harrera-herrialdeko hizkuntza berbera izaten da. Dena den, bada hirugarren kasu nagusi bat ere: litekeena da etorri berriek harrera-lurraldeko hizkuntzetako bat jakitea, baina ez bestea, edo besteak. Azken hori oso ohikoa da, esate baterako, Hego Ameriketatik Hego Euskal Herrira datozenen kasuan (Manterola eta Berasategi, 2011).

Lurralde desberdinetan egindako ikerketek diote ikasle etorkinen eskolako hizkuntzen maila ez dela ikasle autoktonoen parekoa (Navarro, Huguet eta Sansó, 2014; Navarro, Huguet, Sansó eta Chireac, 2012; Siguán, 1998; Serra, 1997; Díaz-Aguado, Baraja eta Royo, 1996; Mesa eta Sánchez, 1996). Egoera horri aurre egiteko, garrantzitsua izango da harrera-herrialdetik era askotako mekanismo eta bitartekoak eskaintzea egoera hori hobetzeko eta etorkinek hizkuntza berri horiek ikas ditzaten; besteak beste, beraien garapen pertsonalerako eta integrazio soziokulturalerako (Etxague, Cenoz eta Uria, 2010). Baina, bestalde, oso garrantzitsua izango da, halaber, etorri berrien hizkuntzak bultzatzea eta sustatzea. Hau da, etorkinek ez ditzatela euren jatorrizko hizkuntzak alde batera utzi, harrera-herrialdeko hizkuntzak ikastearren; jakina delako era berean ikaslearen H1ak H2an duen eragina (Gebauer, Zaunbauer eta Moller, 2012; Horst, White eta Bell, 2010; Vila, 2000; Cummins, 1979).

Eskolan dagoen aniztasun linguistikoa kudeatzeko, hezkuntza-sistema murgiltze-programak edo hezkuntza elebidunetik datozen bitartekoak erabiltzen ari da. Dena dela, autore desberdinek nabarmentzen duten bezala, horrek baditu bere mugak (Serra eta Vila, 2005; Navarro, 2003). Hain justu, Besalú-k eta Vila-k (2007) dioten bezala, bi baldintza dira oinarrizkoak murgiltze-programak aurrera eramateko orduan: bata borondatea, hau da, familien borondatea programa aukeratzeko orduan, eta bigarrena irakasle elebidunaren beharra. Baldintza horiek nekez lor daitezke egungo testuinguruan; izan ere, zaila edo ia ezinezkoa da egun dagoen hizkuntzaaniztasunari erantzungo dion irakasleria eleanitzean pentsatzea. Testuinguru berri horretan, ez du esan nahi murgilketa-programak balio ez duenik, baizik eta, egungo beharrizan linguistiko eta akademikoak asetzeko nahikoa ez direnez, hezkuntza-praktika egoera berrira egokitu beharko dela.

Horiek kontuan hartuta, etorri berriak, bertako hizkuntzak ikasteaz gain, etxeko hizkuntza ere garatzea lortu beharko litzateke. Hala, zentzuzkoa dirudi murgilketa bidezko irakaskuntzaz baliatzeak (Navarro, 2003; Barquín eta beste, 2007), baina, era berean, bestelako esperientziak kontuan hartuta, ezinbestekoa dirudi etorri berrien etxeko hizkuntzak nola edo hala sustatzeak.

Beraz, hizkuntzen eta kulturen erabileraren auzia ez da kontu erraza. Sarri, eskola izan da hizkuntza-berreskurapenerako eta erabilerarako esparru garrantzitsuena. Euskal Herrian ere eskolaren bidez lortu da gazte asko euskalduntzea, eta eskolak euskararen normalizazioan izan duen papera ezin uka daiteke. Horregatik guztiagatik, errealitate berri horren aurrean ere, eskola esparru aproposa izan daiteke hizpide dugun aniztasun linguis- 
tiko eta kultural berri hori kudeatzeko, eta hizkuntzei eta kulturei dagozkien lekua aitortzeko. Horretarako, besteak beste, ezinbestekoa izango da politika, esku-hartze eta programa baliagarriak eta arrakastatsuak martxan jartzea, beharrezkoak diren giza baliabide eta baliabide materialak eskainiz. Baina horretarako beharrezkoa da ere aurretik aztertzea ikasleek kulturarekin eta hizkuntzarekin dituzten harremanak nolakoak diren, hizkuntzaerabilerak eta kultura-praktikak nolakoak diren, ikasleen integrazioa nola gauzatzen ari den, eta abar. Bide horretan, ondorengo lerroetan ikasleen praktika linguistikoak eta hautatzen duten eskola mota ezagutzeko egindako ikerketaren berri ematen da.

\section{HELBURU ETA HIPOTESIAK}

Ikerketaren helburu orokorra Bilboko ikasleek hautatzen duten eskola eta erabiltzen duten edo dituzten hizkuntzak zein diren ezagutzea da, zehazki Derrigorrezko Bigarren Hezkuntzako ikasleen kasuan.

Zehaztu diren helburu espezifikoak honako hauek dira:

1. DBH 2. eta 4. mailako ikasleek hautatzen duten ikastetxearen ezaugarri orokorrak (ikastetxe mota, eredu linguistikoa eta etorkin kopurua) ezagutu eta deskribatzea eta jatorriaren arabera desberdintasunik ote dagoen ikustea. Hala, jatorriaren arabera desberdintasunak egotea espero da.

2. DBH 2. eta 4. mailako ikasleen praktika linguistikoak aztertzea esparruaren (eskola, eskolako ataria, familia eta lagunartea) eta jatorriaren arabera. Hala, esparruaren eta jatorriaren arabera, ikasleen praktika linguistikoetan desberdintasunak egotea espero da.

\section{METODOLOGIA}

Ikerketa, alde batetik, deskriptiboa da, datuak jaso diren uneko errealitatea deskribatzea duelako xede. Bestetik, korrelazionala da, hizkuntza praktiken eta euskara-erabilera eta -ezagutzaren, eta jatorriaren arteko korrelazioak egin direlako.

\section{Lagina}

Lagina Bilboko 989 ikaslek osatzen dute, Derrigorrezko Bigarren Hezkuntzako 2. mailako 565 ikaslek eta 4. mailako 424 ikaslek. Ikasle horien \% 14,6 ( $\mathrm{n}=145)$ Europako beste herrialde batetik edo Europatik kanpoko herrialde batetik etorritako ikasleak dira. Laginketa ordezkaga- 
rria izan zedin, ausazko laginketa estratifikatu bat egin da, honako maila hauek kontuan izanik: ikastetxe mota (Publikoa-Itunpeko erlijiosoa-Itunpeko ikastola), eredu linguistikoa (A: ikasketak espainieraz, eta euskara ikasgai gisa - B: ikasketak euskaraz eta espainieraz - D: Ikasketak euskaraz, eta espainiera ikasgai moduan - X: ikastetxean ez dute euskararik) eta etorkin kopurua ikastetxean (Baxua: <\% 5 - Erdibidekoa: \% 5-40 - Altua: $>\%$ 40). Horretarako 11 eskola hautatu dira. Laginketa Eusko Jaurlaritzako Hezkuntza Sailak bideratutako 2010-2011 ikasturteko datuetan oinarritu da.

\section{Datu-bilketarako tresnak}

Datuen bilketa inkesta bidez egin da. Inkesta hau aurretik Donostiako DBHko 2. mailako eta DBHko 4. mailako ikasleekin erabili da (Berasategi, 2014; Berasategi eta Larrañaga, 2014; Larrañaga, Azurmendi, Berasategi eta Etxepeteleku, 2010). Zehazki lan honetan jasoko ditugun emaitzak atal batzuei buruzkoak dira: datu soziodemografikoak, hizkuntza-praktika esparru desberdinetan, euskararen ezagutza eta euskararen erabilera.

\section{Datu-bilketa eta azterketa}

Estatistika irizpideak kontuan izanik, Bilboko ikastetxeetan oinarrituta egin da lagina. Metodologia deskriptibo eta korrelaziozkoa erabili da. Analisi estatistikoak egiteko erabilitako teknika estatistikoa khi karratua izan da. Galde-sorta pasatzeko, ikastetxeetara bertaratu ginen. Ikasleek eskolaorduetan bete zuten galde-sorta, Internet bidez «Encuesta fácil» aplikazioa erabiliz. Gure ikerketan parte hartzea ez zen derrigorrezkoa. Galde-sortaren hizkuntzari dagokionez, elebitan zegoen (euskaraz eta espainieraz) eta ikasleek nahi zuten hizkuntza hauta zezaketen erantzuteko.

\section{EMAITZAK}

\section{DBH 2. eta 4. mailako ikasleak eta ikastetxearen ezaugarriak (ikastetxe mota, eredu linguistikoa eta etorkin kopurua)}

Aztertutako bi taldeen arteko erkaketan (autoktonoak eta etorkinak), 1. taulan ikus daiteke desberdintasunak esanguratsuak direla. Ikasle autoktonoen \% 63,7 ikastetxe publikoetan matrikulatuta dago $(\mathrm{N}=530), \% 21,9$ itunpeko ikastoletan $(\mathrm{N}=182)$, eta \% 14,4 itunpeko ikastetxe erlijiosoe$\tan (\mathrm{N}=120)$. Ikasle etorkinen kasuan, ordea, gutxiago dira ikastetxe pu- 
blikoan ikasten dutenak ( $\% 53,1 ; \mathrm{N}=77)$, eta nabarmen gehiago dira, autoktonoekin alderatuz, itunpeko ikastetxe erlijiosoetan ikasten dutenak (\% 46,9; $\mathrm{N}=68$ ). Aztertutako laginean, ez dago ikasle etorkinik itunpeko ikastoletan (1. taula).

Beraz, ikus dezakegu desberdintasunak daudela ikasle autoktonoen eta ikasle etorkinen artean ikastetxe motari dagokionez. Ikasle etorkinek era nabariagoan hautatzen dituzte itunpeko ikastetxe erlijiosoak, eta autoktonoek, aldiz, maila nabarmenagoan itunpeko ikastolak.

1. taula

Ikasleak, ikastetxe motaren arabera

\begin{tabular}{|c|c|c|c|c|c|}
\hline & \multicolumn{2}{|c|}{ Autoktonoak } & \multicolumn{2}{|c|}{ Etorkinak } & \multirow{2}{*}{$\chi^{2}$} \\
\hline & $N$ & $\%$ & $N$ & $\%$ & \\
\hline Publikoa & 530 & 63,7 & 77 & 53,1 & \\
\hline Itunpeko erlijiosoa & 120 & 14,4 & 68 & 46,9 & $101,620^{*}$ \\
\hline Itunpeko ikastola & 182 & 21,9 & - & - & \\
\hline Guztira & 832 & 100,0 & 145 & 100,0 & \\
\hline
\end{tabular}

* $\mathrm{p}<0,001$.

Ikastetxean dagoen etorkin kopuruari dagokionez, ikasle autoktonoen gehiengoa etorkin gutxi edo \% 5-40 bitartean duten ikastetxeetan kokatzen da (\% 43,9; $\mathrm{N}=365$ eta $\% 48,8 ; \mathrm{N}=406)$; aldiz, gutxiengoa dago $\% 40$ baino gehiagoko etorkin kopurua duten ikastetxeetan $(\% 7,3 ; \mathrm{N}=61)$.

Etorkinen kasuan, alderantziz gertatzen da: gutxiengoa dago etorkinen kopuru baxua duten ikastetxeetan (\% 4,8; $\mathrm{N}=7$ ), eta gehiengoa (\% 53,1; $\mathrm{N}=77$ ) etorkin ugariko ikastetxeetan (2. taula).

2. taula

Ikasleak, ikastetxeak duen etorkin kopuruaren arabera

\begin{tabular}{|c|c|c|c|c|c|}
\hline & \multicolumn{2}{|c|}{ Autoktonoak } & \multicolumn{2}{|c|}{ Etorkinak } & \multirow{2}{*}{$\chi^{2}$} \\
\hline & $N$ & $\%$ & $N$ & $\%$ & \\
\hline $\begin{array}{l}<\% 5 \\
\% 5-40 \\
>\% 40\end{array}$ & $\begin{array}{r}365 \\
406 \\
61\end{array}$ & $\begin{array}{c}43,9 \\
48,8 \\
7,3\end{array}$ & $\begin{array}{r}7 \\
61 \\
77\end{array}$ & $\begin{array}{r}4,8 \\
42,1 \\
53,1\end{array}$ & $233,754 *$ \\
\hline Guztira & 832 & 100,0 & 145 & 100,0 & \\
\hline
\end{tabular}

* $\mathrm{p}<0,001$. 
Eredu linguistikoari dagokionez, taldeen arteko erkaketan (autoktonoak eta etorkinak), desberdintasunak esanguratsuak dira. Autoktonoen gehiengoak, lagin osoko datuetan gertatzen den bezala, D eredua aukeratzen du (\% 65,6; $\mathrm{N}=546$ ). Ikasle etorkinen kasuan, ordea, D eredua hautatzen dutenen ehunekoa baxuagoa da, \% 13,8k baino ez baitu eredu hori hautatzen $(\mathrm{N}=20)$. Alderantziz, A eredua hautatzen dutenen kopurua altuagoa da etorkinen kasuan, autoktonoekin alderatuz (3. taula).

3. taula

Ikasleak, eredu linguistikoaren arabera

\begin{tabular}{l|rr|rr|c}
\hline & \multicolumn{2}{|c|}{ Autoktonoak } & \multicolumn{2}{c|}{ Etorkinak } & \multirow{2}{*}{$\chi^{2}$} \\
\cline { 2 - 5 } & \multicolumn{1}{|c|}{$N$} & $\%$ & \multicolumn{1}{c}{$N$} & $\%$ & \\
\hline A eredua & 73 & 8,8 & 71 & 49,0 & \\
B eredua & 174 & 20,9 & 36 & 24,8 & \\
D eredua & 546 & 65,6 & 20 & 13,8 & $210,407 *$ \\
X eredua & 2 & 0,2 & 3 & 2,1 & \\
Zehaztu gabe & 37 & 4,4 & 15 & 10,3 & \\
\hline Guztira & 832 & 100,0 & 145 & 100,0 & \\
\hline
\end{tabular}

* $\mathrm{p}<0,001$.

Hortaz, lehenengo hipotesia baieztatu egiten da; izan ere, desberdintasunak daude ikasle autoktonoen eta etorkinen artean, ikastetxe motaren, eredu linguistikoaren eta ikastetxean dagoen etorkin kopuruaren arabera.

\section{DBH 2. eta 4. mailako ikasleen praktika linguistikoak, esparruaren (eskola, eskolako ataria, familia eta lagunartea) eta jatorriaren arabera}

Esparruen arabera, 4. taulari so, ikus daiteke desberdinak direla ikasleen hizkuntza-praktikak; bai esparruen arabera, baita jatorriaren arabera ere. Esparruetako hizkuntza-erabilerari dagokionez, eskolan erabiltzen da gehien euskara, baina eskolatik aldentzean hizkuntza horren erabilera nabarmen jaisten da. Espainiera, aldiz, nagusitzen da eskolaz kanpoko esparruetan.

Taldeak (autoktonoak eta etorkinak) konparatzean ikusten denez, autoktonoak dira euskara gehien erabiltzen dutenak; batez ere, eskolan erabiltzen dute euskara $(\%$ 57,5). Gainerako esparruetan (eskolako atarian, familian eta lagunartean), nabarmen jaisten da euskararen erabilera, eta igo egiten da espainierarena. Etorkinek ere eskola-eremuan erabiltzen 
dute gehien euskara, baina autoktonoek baino maila nabarmen baxuagoan $(\%$ 17,2). Erabilera hori eskola-esparrutik aldentzean ia hutsala da.

Beste hizkuntzei dagokienez, ikus daiteke familian erabiltzen direla gehien hizkuntza horiek. Etorkinak dira beste hizkuntz batzuk gehien erabiltzen dituztenak $(\% 21,9)$. Familiatik kanpoko esparruetan, hizkuntzaren erabilera oso txikia da etorkinen kasuan ere; ia ez da antzeman ere egiten (4. taula).

4. taula

Ikasleek hainbat esparrutan egiten duten hizkuntza, ikasleen jatorriaren arabera

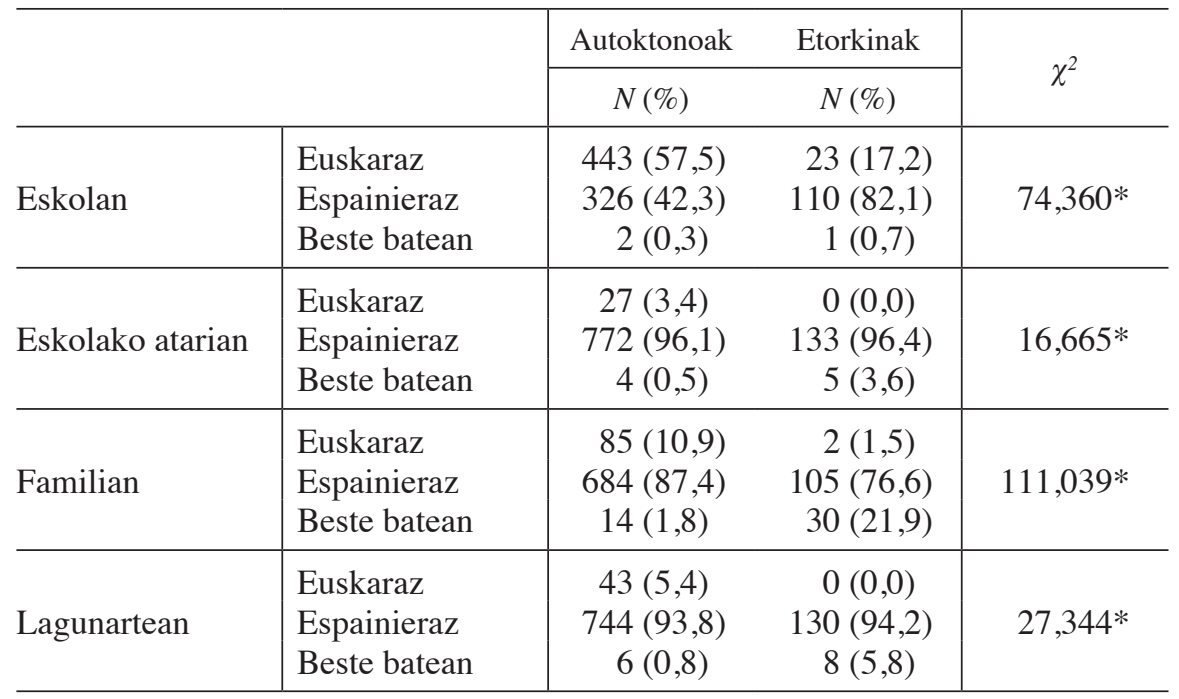

* $\mathrm{p}<0,001$.

Hala, bigarren hipotesia ere baieztatu egiten da; hain zuzen, desberdintasunak aurkitu dira, esparruari (eskola, eskolako ataria, familia eta lagunartea) eta jatorriari dagokienez, euskararen erabileran.

\section{ONDORIOAK}

Aztertutako Bilboko ikasleetan ikusten dugu, oro har, gehiengoak ikastetxe publikoa hautatzen duela; ikasle etorkinek, ordea, maila altuagoan aukeratzen dute itunpeko ikastetxe erlijiosoa. Zentzu horretan, aipatzekoa da EAEko populazioan oinarrituta egin diren beste ikerketa batzuek emandako datu orokorragoetan ikusten dela, orokorrean, ikasle etorkinek ikaste- 
txe publikoetara joateko joera dutela, baina beste erkidego batzuetan baino kontzentrazio-efektu nabarmenagoarekin (Septién, 2006). Izan ere, proportzionalki, sare pribatuko itunpeko ikastetxeen kopurua publikoena baino handiagoa denez, handiagotu egiten da atzerriko ikasleen desoreka, bi sareen artean. Gure kasuan ikerketa lagina Bilbon kokatu denez, ikasle etorkinen hautu hori ez da hainbeste nabarmentzen, Bilbon itunpeko ikastetxe erlijiosoen eskaintza beste barrutietakoa baino altuagoa baita, eta horrek eragina du datuetan, ikasle etorkin kopuru esanguratsua dagoelako itunpeko ikastetxe erlijiosoetan. Aipagarria da ere ez dagoela ikasle etorkinik itunpeko ikastoletan. Kontuan hartu behar da aztertu dugun lagina Derrigorrezko Bigarren Hezkuntzako ikasleek osatzen dutela, eta segur aski maila baxuagoetan badirela ikasleak.

Ikasle etorkinak etorkin kopuru altuagoa duten ikastetxeetan kokatzen dira, eta aurretik egindako ikerketek ere hori diote (Vila, 2005). Horrek dakar, besteak beste, zenbait ikastetxetan ikasle etorkinak pilatzea. Pilaketa horren arrazoiak ugari dira; beste batzuen artean, gurasoen maila sozioekonomikoa. Faktore garrantzitsu horrek erakusten digu etorkinak, arrazoi ekonomikoengatik, gune jakin batzuetan kontzentratzen direla (Septién, 2006).

Eredu linguistikoari dagokionez, berriz, ikusten da autoktonoen gehiengoak D eredua hautatzen duela, baina etorkinen kasuan ez dela hautu hori maila berean egiten. Aurretik egindako hainbat ikerketak ere erakutsi dute errealitate hori (Ikuspegi, 2010; Septién, 2006; Zapata, 2006). Egoera honek desabantaila egoeran kokatzen ditu ikasle etorkinak bertakoen aurrean: batzuek bi hizkuntza menderatuko dituzte, eta besteek, aldiz, hizkuntza bakarra.

Ikasleek hitz egiten dituzten hizkuntzei dagokienez, oro har, ikusten da eskola dela euskararentzat babesgunea, bertan erabiltzen baita gehien; eskolaz kanpoko esparruetan, ordea, bai autoktonoen bai etorkinen artean espainiera da nagusitzen dena. Kontuan hartu behar da Bilboko testuingurua ez dela oso aldeko eta horrek ere eragina duela aztertutako datuetan, ikasleek, eskolatik aldentzean, kalean nagusi den hizkuntzara salto egiten baitute. Etorkinek erabiltzen duten euskara gutxien, nahiz horiek ere, autoktonoen antzera, eskolan erabiltzen duten gehien. Aurretik emandako datuek lagundu dezakete etorkinen euskara maila baxuagoa ulertzen; izan ere, etorkinek aukera gutxiago dute euskara ikasteko, neurri baxuagoan aukeratzen baitute D eredua, eta etorkin portzentaje altuagoa duten zentroetan kokatzen dira. Etorkinak ere nabarmenago kokatzen dira itunpeko zentro erlijiosoetan, eta horiek gehienetan eskaintzen duten eredua A eta B eredua izaten da.

Beste hizkuntzen presentzia ere ageri da aurrera eraman dugun ikerketan, baina hizkuntza horiek gehienbat familian erabiltzen dira. Aurretik Gasteiz hirian egindako ikerketa batean ere ikusten da familia dela hizkuntza horien babesleku (Ibarraran, Lasagabaster eta Sierra, 2007). 
Datuak kontuan izanda, argia da euskararen egoera ez dela oso aldekoa aztertutako laginean: hizkuntza horrentzat eskola bihurtzen da babesgune eta bertatik aldentzean espainiera nagusitzen da. Egoera horri aurre egiteko, interesgarria litzateke eremu formalean ez ezik eremu informalean ere erabilera lantzeko guneak sortzea, eta bide horretan eskolaz kanpoko jarduerak izan daitezke jomugetako bat (Soziolinguistika Klusterra \& Eusko Jaurlaritza, 2012). Bestalde, kontuan izanik ikasle etorkinak direla euskararen erabilera nabarmen baxuago egiten dutenak, garrantzitsua litzateke egoera hori hobetzeko mekanismo eta bitartekoak bideratzea. Ildo horretan, ereduaren aukeraketa izango da kontuan hartu beharreko gakoetako bat; jakina baita A eta B ereduetan ez dela ikasleen euskalduntzea lortzen. Horrez gain, euskararen ikaskuntza eta erabilera hobetzeari begira, besteak beste, mekanismo eta bitartekoak jarri beharko dira ikastetxeetan eta, ahozkotasunarekin eta motibazioarekin batera, metodologiari erreparatzea garrantzitsua izango da. Era berean, H1ak H2an duen eragina kontuan izanik, garrantzizkoa izango da etorri berrien hizkuntzak eskolan nola edo hala sustatzea (Gebauer, Zaunbauer eta Moller, 2012; Horst, White eta Bell, 2010; Vila, 2000; Cummins, 1979).

\begin{abstract}
The work presented is housed in a broader framework of research. This article describes the characteristics of the type of school and linguistic practices (Basque, Spanish and other languages) of the students (indigenous and immigrant) from 2 and 4 of the secondary education. After reviewing the demographic data and policies of the Department of Education of the Basque Government regarding the incorporation of new students to the Basque Education System, is applicable to the study of the characteristics of students of Bilbao on a sample of 989 pupils of 2 and 4 course of ESO. The type of school that students choose considering the type of school, the percentage of immigrant students and the language model are analyzed. On the other hand, the practices of the students in different spaces (at school, on the playground, family and friends) are analyzed. Finally, certain actions are planned that pose optimize and rethink strategies to improve the use of Basque and the use of immigrant languages.
\end{abstract}

Keywords: Secondary education, language models, type of center, immigrant students, linguistic practices. 
El trabajo que se presenta está ubicado en un marco más amplio de investigación. En este artículo se presentan las características del tipo de centro y las prácticas lingüísticas (euskara, español y otras lenguas) del alumnado (autóctono e inmigrante) de 2 y 4 de la E.S.O. Revisados los datos socio demográficos y las políticas del Departamento de Educación del Gobierno Vasco respecto a la incorporación del alumnado recién llegado al Sistema Educativo Vasco, se procede al estudio de las características del alumnado de Bilbao sobre una muestra de 989 del alumnado de 2 y 4 de la ESO. Se analizan el tipo de centro que el alumnado elige teniendo en cuenta, la titularidad del centro, el porcentaje de alumnado inmigrante y el modelo lingüístico. Por otro lado, se analizan las prácticas de dicho alumnado en diferentes espacios (en la escuela, en el patio, en la familia y con los amigos). Finalmente, se plantean ciertas actuaciones que plantean optimizar y reconsiderar estrategias para mejorar el uso del euskara y el uso de las lenguas del alumnado inmigrante.

Palabras clave: Educación secundaria, modelos lingüísticos, tipo de centro, alumnado inmigrante, prácticas lingüísticas.

Le travail présenté est logé dans un cadre plus large de la recherche. Cet article décrit les caractéristiques du type de pratiques scolaires et linguistiques (basques, espagnol et autres langues) des étudiants (autochtones et immigrés) 2 et 4 de l'ESO sont présentés.Modifiéles données et les politiques du ministère de l'Éducation du Gouvernement Basque concernant l'incorporation de nouveaux étudiants au système éducatif basque sociodémographiques est applicable à l'étude des caractéristiques des étudiants de Bilbao sur un échantillon de 989 élèves de 2 et 4 de ESO. Le type d'école que les étudiants choisissent compte tenu du type de l'école, le pourcentage d'élèves immigrants et le modèle de langage sont analysés. D'autre part, les pratiques des étudiants dans différents espaces (à l'école, sur le terrain de jeu, famille et amis) sont analysés. Enfin, certaines actions qui présentent optimiser et repenser les stratégies visant à améliorer l'utilisation de la langue basque et de l'utilisation des langues des élèves immigrants se posent.

Mots-clé: l'enseignement secondaire, les modèles de langue, type de centre, les élèves immigrants, les pratiques linguistiques. 


\section{ERREFERENTZIAK}

Agindua, 1998ko uztailaren 30ekoa, Hezkuntza, Unibertsitate eta Ikerkuntza sailburuarena, hezkuntzaren arloko hainbat ekintza eta neurri arautzen dituena, gizarte edo kulturaren ikuspegitik besteak baino egoera txarragoan diren ikasleentzat eta eskolara egokitzeko zailtasun handiak dauzkaten ikasleentzat (EHAA 164. 1998-8-31).

Aierdi, X. eta Moreno, G. (2011). EAEn egoitza-baimena duten biztanle atzerritarrak. In G. Moreno \& X. Aierdi (arg.), EAEko Immigrazioari buruzko 2010. eko urtekaria.Zarautz: Ikuspegi@k-Immigrazioaren Euskal Behatokia.

Albite, P. (2008). Migrazioak, kultura-aniztasuna eta estaturik gabeko nazioak. Euskal Herriaren erronkak. Jakin, 165, 31-75.

Aramaio, I. (2004). Estatus kanpoko etorkinak eta hizkuntza normalizazioa EAE-n: administrazio publikoaren eta herri mugimenduaren ahaleginak. BAT Soziolinguistika aldizkaria, 32, 33-40.

Barquín, A., Fernandez, P., Ibarra, J., Ortega, I., Ruiz, U., Serna, A. eta Zulaika, T. (2007). Hizkuntzen irakaskuntza iritsi berriekin. Hik Hasi, 119.

Basurko, F., Galarreta, X., Lukas, J.F. eta Pikabea, I. (2006). Hezkuntza-kooperatiben egoera EAE-n. Tantak, 35, 45-60.

Berasategi, N. (2014). Hizkuntza eta kultura aniztasuna Bilboko eskoletan. Euskararen erabileran eta euskal kultur praktikan eragiten duten faktoreak. Doktore-tesia, Euskal Herriko Unibertsitatea.

Berasategi, N., eta Larrañaga, N. (2014). Diversidad linguística y cultural en el contexto educativo. Actitudes y prácticas. Inguruak, 61-69.

Besalu, X. eta Vila, I. (2007). La buena educación. Libertad e igualdad en la escuela del siglo XX. Madrid: Catarata.

Castels, S. eta Miller, M.J. (2003). The age of migration. New York: Guilford Press.

Cummins, J. (1979). Linguistic interdependence and the educational development of bilingual children. Review of Educational Reserach, 49, 222-251.

Díaz-Aguado, M.J, Baraja, A. eta Royo, P. (1996). Estudio sobre la integración escolar de los alumnos extranjeros y el aprendizaje del castellano como segunda lengua. In M. J. Díaz-Aguado, Escuela y tolerancia (101-154 or.). Madril: Piramide.

Euskadiko Eskola Kontseilua (2013). Hezkuntza Euskadin, 2010-2012. Eskuragarri: http://www.consejoescolardeeuskadi.hezkuntza.net/c/document_library/ get_file?uuid=3a49da40-1a29-4a07-a89c-234d8d195cba\&groupId=17937

Etxague, X., Cenoz, J., eta Uria, M. (2010). Inmigración, lenguas oficiales y educación en el País Vasco. Segundas Lenguas e Inmigración en red, 3, 6-20.

Etxeberria, F. (2006). Enseñanza de las lenguas con alumnos inmigrantes. Eusko news \& Media. 2014ko otsailaren 1ean kontsultatua. Eskuragarri: http://www. euskonews.com/0339zbk/gaia33906es.html.

Euskararen Kontseilua (2006). Aniztasunean. Euskara eta immigrazioa hezkuntza sisteman. Jardunaldiak 06-XII-18/19. Bilbo. Dokumentu argitaragabea.

Eusko Jaurlaritza (2003). Ikasle etorkinak artatzeko programa. Vitoria-Gasteiz: Eusko Jaurlaritza.

Eusko Jaurlaritza (2004). Ikasle etorkinak artatzeko programa. Vitoria-Gasteiz: Eusko Jaurlaritza. 
Eusko Jaurlaritza (2007). Kulturartekotasuna eta Ikasle Berrien Inklusiorako Programa 2007-2010. Vitoria-Gasteiz: Eusko Jaurlaritza.

Eusko Jaurlaritza (2009). IV . Mapa Soziolinguistikoa. Vitoria-Gasteiz: Eusko Jaurlaritza.

Eustat (2015). Lurralde historikoak atzerritar portzentaiaren arabera. Behin-behineko datuak 2015. Eskuragarri: http://ikuspegi inmigracion.net/eus/estadisticas/estadisticas.php

Gebauer, S. K., Zaunbauer, A. C. M. eta Möller, J. (2013). Cross-Language Transfer in English Immersion Programs: Reading Comprehension and Reading Fluency. Contemporary Educational Psychology, 38, 64-74.

Horst, M., White, J. eta Bell, P. (2010). First and second language knowledge in the language classroom. Inter. J. Biling.,14, 3, 331-349.

Ibarraran, A., Lasagabaster, D., eta Sierra, J.-M. (2007). Inmigración y aprendizaje de lenguas en contexto bilingue. Bilbo: Lete.

Jaussi Nieva, M.L. eta Rubio, T. (1998). Kultura-arteko hezkuntza. Eskola aniztasun etniko eta kulturalari hezkuntza erantzuna emateko orientabideak. Gasteiz: Eusko Jaurlaritzaren Argitalpen Zerbitzu Nagusia.

Larrañaga, N., Azurmendi, M.-J., Berasategi, N., eta Etxepeteleku (2010). Aniztasun linguistiko eta kulturala euskal eskolan. Inguruak, 61-69.

Manterola, I. eta Berasategi, N. (2011). Hizkuntza gutxituen erronkak. Bilbo: Udako Euskal Unibertsitatea.

Mesa, M.C. eta Sánchez, S. (1996). Educación y situaciones bilingues en contextos multiculturales. Estudio de un caso. Melilla: Secretaria General Técnica del MEC.

Migrazioetarako Nazioarteko Erakundeak (2011). Informe sobre las informaciones en el mundo. Ginebra: Organización Internacional para las Migraciones.

Navarro, J.L. (2003). Inmigración en España y conocimiento de la lengua castellana. El caso de los escolares inmigrados en Aragón. Doktore-tesia, University of Lleida.

Navarro, J.L. eta Huguet, A. (2010). Conocimiento del catalán y castellano por parte del alumnado inmigrante. Revista de Educación, 352, 245-265.

Navarro, J.L., Huguet, A. eta Sansó (2014). Competencias linguísticas y alumnado inmigrante en cataluña. El caso del colectivo de origen hispanohablante. Educación XXI, 17, 2, 361-382.

Navarro, J.L., Huguet, A., Sansó, C. eta Chireac, S.M. (2012). Acerca de la competencia linguística del alumnado de origen inmigrante en la Educación Secundaria en Cataluña. El papel del tiempo de estancia y lengua familiar. Anales de psicología, 28, 2, 457-464.

Septién, J. (2006). Mugarik gabeko eskola. Ikasle etorkinen irakaskuntza Araban. Vitoria-Gasteiz: Ararteko.

Serra, J.M. (1997). Inmersió linguística, rendiment acadèmic i classe social. Bartzelona: Horsori.

Serra, J.M. eta Vila, I. (2005). Lenguas, escuela e inmigración en Catalunya. In D. Lasagabaster \& J.M. Sierra (arg.), Multilinguismo, competencia linguística y nuevas tecnologías (pp. 75-89). Bartzelona: Horsori.

Huguet, A. eta Navarro, J.L. (2006). Inmigración y resultados escolares: lo que dice la investigación. Cultura y Educación, 18, 2, 117-126.

Siguán, M. (1998). La escuela y los inmigrantes. Bartzelona: Paidós. 
Soziolinguistika Klusterra eta Eusko Jaurlaritza (2012). ARRUE proiektua. Ebaluazio diagnostikoa 2011: Ikasleen hizkuntza erabileraren datuak. Emaitza nagusien txostena. http://www.soziolinguistika.org/files/ED2011_Emaitza_ nagusien_txostena.pdf).

Uranga, B., Aierdi, X., Idiazabal, I., Amorrortu, E., Barreña, A., eta Ortega, A. (2008). Hizkuntzak eta Inmigrazioa. Lenguas e Inmigración. Bilbo: Ikuspegi, UNESCO etxea, UPV/EHU.

Vila, I. (2000). Inmigración, educación y lengua propia. In AA.VV., La inmigración extranjera en España. Los retos educativos (145-166 or.). Fundación La Caixa: Barcelona.

Vila, I. (2005). ¿Nivel sociocultural o desconocimiento de la lengua? Perspectiva Cep: revista de los centros del profesorado de Andalucia, 23-54.

Zapata, M. (2006). Etorkinak eta hizkuntza ereduak. Vitoria-Gasteiz: Eusko Jaurlaritza. 